\title{
Maureen Baker
}
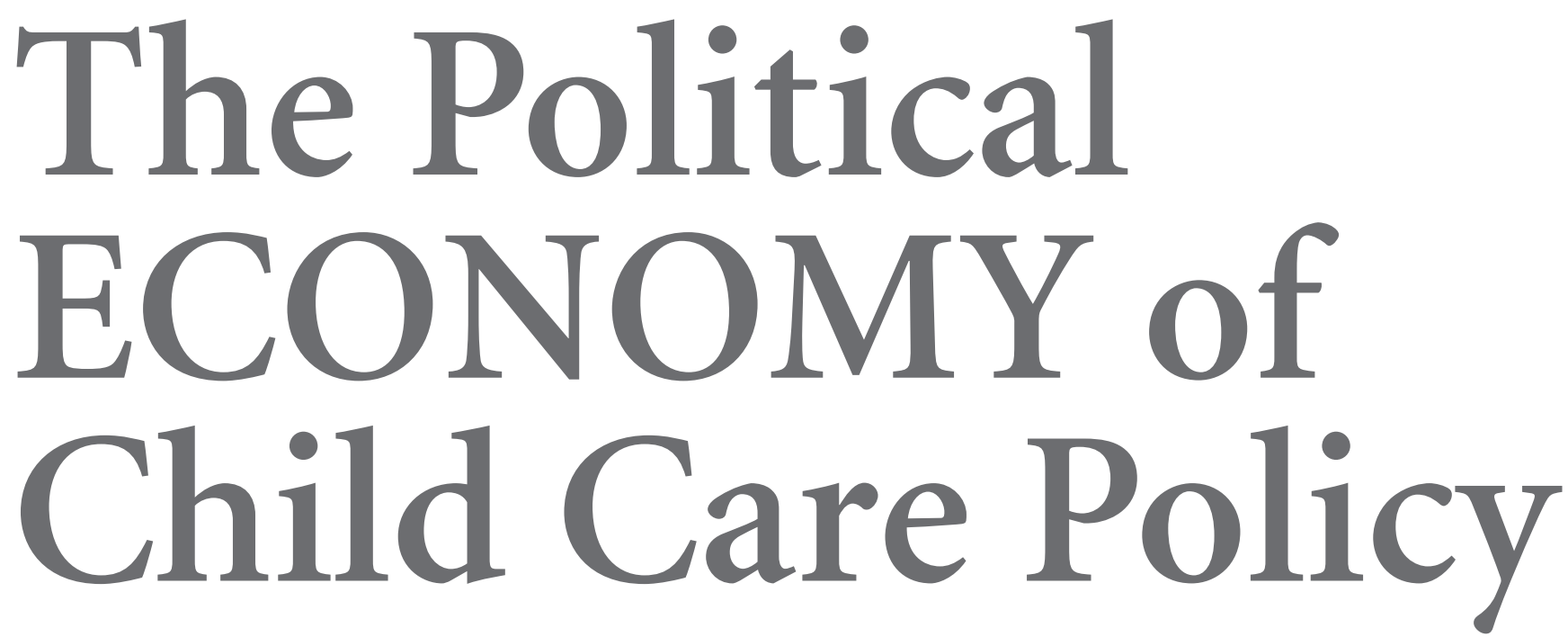

\section{Contradictions in New Zealand and Canada}

\section{Introduction}

In countries like New Zealand and Canada, often classified as 'liberal' welfare regimes, child care was historically viewed as a private matter of little concern to governments or employers. Nevertheless, early in the 2oth century governments supported maternal care at home by providing tax relief to male-breadwinner families, but also established care and protection programmes for disadvantaged children. In the 1940s, both countries developed universal child allowances to help parents with childrearing costs. By the 1970 s they were providing subsidies for early childhood education and care while continuing to offer income support programmes for disadvantaged parents caring for children at home (Baker, 2006; Kedgley, 1996; May, 1997; McClure, 1998).

Maureen Baker is Professor of Sociology at the University of Auckland. She has published widely on family trends and cross-national family policies.
This article focuses on early childhood education and care (ECEC), which can include school- or centre-based education and care (public and private kindergartens, daycare centres, nurseries or crèches) as well as government-regulated group care in private homes. However, it does not include informal care by parents, relatives or sitters. Historically, the most prevalent support for ECEC in New Zealand and Canada hasinvolved subsidising group care for children from low-income households and of sole parents, but subsidies can vary from a fraction of parental fees to covering all of them. If policy makers see ECEC mainly as education, they may subsidise only a few hours a week, but if they want to encourage maternal employment they may subsidise full-day and full-week child care. Of course, states support families in a number of other ways as well. For example, child tax benefits and child allowances provide invaluable assistance, but they are omitted from this article because they focus on parenthood rather than care 
work. In other words, these programmes are not targeted to the physical or handson care of children.

In the past decade, both New Zealand and Canada have improved work-related ECEC, which is the main concern of this article. Maternal employment rates and child care support in these 'liberal' states are compared to the OECD average and the 'social democratic' countries of Denmark and Sweden, where ECEC policy differences are most apparent (Bonoli and Reber, 2010). The main argument of this article is that ECEC reforms in New Zealand and Canada have improved service availability and enabled more mothers to retain paid work and
Welfare regimes, political parties and models of family

Some continuity is apparent in the design, delivery and funding of social benefits and services, even though welfare states were established and modified over many years with input from different political parties and interest groups (EspingAndersen, 1990; Korpi, 2000). Researchers have noted patterns in the assumptions underpinning the development of social programmes based on why some people are in need, how the state should assist them and how services are best delivered. The assumptions and the services/benefits developed from them have been called 'welfare regimes'. Specific jurisdictions

\section{... all liberal governments now encourage able-bodied adults to become self-supporting through paid work, unless they have sole responsibility for young children or are supported by other family members.}

support their households. Reforms have also strengthened public discourse about the importance of parental employment, yet additional policy changes and social services are required to enable parents to manage earning and caring more effectively.

Comparative and historical analysis is valuable because it shows not only a range of policy options but also the demographic, economic and political conditions under which policies are conceptualised, debated and restructured. Comparisons also reveal that some governments give priority to children's care and education while protecting parental working conditions and employment equity. Other governments say they are 'strengthening families', while deregulating labour markets, tightening eligibility for income support, and expecting parents to cope with little assistance. In reality, most states have made significant policy trade-offs, reducing certain forms of family support while improving others (Baker, 2006; Beach et al., 2009; Hantrais, 2004). have been found to favour one type of regime over the years, depending on the philosophy of governing parties, the power of various interest groups, political coalitions and prevalent sociocultural ideas.

Considerable controversy has existed about welfare regimes and how to classify specific countries. One classification, developed by Esping-Andersen (1990) and widely used in cross-national research, labelled regimes as 'liberal' if they assume that individuals should rely on household earnings and that the state should intervene mainly when families cannot cope. 'Corporatist' or 'conservative' regimes tended to preserve genderand class-based status differentials by focusing on social insurance programmes that share the cost of social protection for long-term employees. 'Social democratic' regimes sought to reduce inequality based on gender and social class through universal programmes and progressive taxation (ibid.). Both New Zealand and Canada have been labelled 'liberal' states under this classification (O'Connor et al.,
1999; Baker, 2006), suggesting that they generally rely on employment earnings to ensure well-being while providing targeted benefits for needy households. However, this label has been disputed for New Zealand by researchers such as Castles and Shirley (1996), who preferred the 'wage-earner's welfare state'. They argued that New Zealand (and Australia) differed historically from the liberal states by focusing more on wages and employment benefits, but conceded that New Zealand especially has changed since the 1990 .

This article uses the 'liberal' label for both New Zealand and Canada, further arguing that similarities were always more apparent in family policies than in employment-related programmes (Baker, 2006). Different welfare regimes often incorporate varying assumptions about family composition, the expected division of labour by gender, and the appropriate role for the state in family life (Leira, 2002). These enduring assumptions suggest that social provision becomes institutionalised, with vested interests discouraging radical reform. However, new ideas from interest groups, international organisations or changes in family demography can lead to policy restructuring if those who introduce the ideas can justify them within the existing culture (Béland, 2005).

Both countries share similarities in recent governance and currently have centre-right governments. New Zealand had a Labour-led government from 1999 to 2008, while Canada had a centre-left Liberal government from 1993 to 2006. Political parties also tend to conceptualise family life in particular ways, offering more or less support for specific 'models of family'. Generally, conservative or right-of-centre parties have talked about 'parental choice' but actually based many policies around the male-breadwinner family, viewing wives primarily as care providers even when they are employed. Left-of-centre parties have typically offered more support to the 'parent-worker', mother-led households and nuclear family alternatives (Bonoli and Reber, 2010). However, all liberal governments now encourage ablebodied adults to become self-supporting 
through paid work, unless they have sole responsibility for young children or are supported by other family members.

\section{Paid work as the 'solution' to poverty?}

Affordable child care tends to raise maternal employment rates (Roy, 2006), which increased in both countries throughout the 1980s and 1990s. These rates still remain higher in Canada, but are especially high in Sweden and Denmark (OECD, 2007a). As Table 1 indicates, the younger the child and the more children per household, the lower are the maternal employment rates, especially in New Zealand.

Mothers often use part-time work to manage child care responsibilities, but few fathers work part-time as they are typically seen as major household earners (Ranson, 2009; Baker, 2010). As Table 2 shows, over one third of employed women in New Zealand worked part-time in 2007, which was above the Canadian rate of $26.1 \%$, the OECD average of $25.6 \%$ and Sweden's rate of $19.7 \%$, although there are some variations in the Swedish definition of part-time work ${ }^{1}$ (OECD, 2009, p.93).

In both Canada and New Zealand, political discourse suggests that parental employment is the main route out of poverty (Lunt et al., 2008; Vosko, 2009), but child poverty rates ${ }^{2}$ for employed parents vary cross-nationally. As Table 3 indicates, nearly one third of employed sole parents are 'poor' in Canada and New Zealand compared to $4 \%$ in Denmark and 6\% in Sweden. This table shows that having a job reduces poverty rates but employment does not pull all households out of poverty, as low-wage work is widespread in the liberal states and mothers with young children often shorten their working hours to provide care. If sole parents are outside paid work, $48 \%$ are poor in New Zealand and $89 \%$ in Canada, compared to $20 \%$ or less in Sweden and Denmark (OECD, 2009, p.93). These comparisons indicate that it is possible to reduce family poverty and improve well-being whether parents are employed or receiving state income support.

Policy discourse in both countries emphasises the importance of responsible parenting (Baker, 2006), yet less public support is offered for employed mothers than in the northern European countries (Korpi, 2000; OECD, 2007a). In addition, public discourse in New Zealand and Canada has blamed 'workless' parents for their poverty but continues to praise professional women 'choosing' to provide care work for preschoolers at home (Baker, 2008). Low-income mothers have been encouraged into employment by more affordable child care, social benefit cuts and public discourse elevating the value of earnings for the poor. However, providing ECEC for middle-income parents has been more controversial in both countries because it requires greater reallocation of public resources, moves away from the liberal focus on lowincome households, and strengthens the value of maternal employment at the risk of downplaying care work.

\section{Pre-2000 child care support}

Early childhood education and care services enjoy a long history, but lobbying for state support has been contentious in many jurisdictions (Baker, 2006; Jenson and Sineau, 2001). Preschool or nursery school has been seen as a necessary and enriching part of early education in Europe since the 19th century, but many preschools in liberal and corporatist states were sponsored by private educational foundations rather than the state. Countries with a tradition of social democracy have long expected women to earn a living and contribute to national productivity. To enable mothers to remain in the workforce, these states provided public child care and family leave entitlements, which came to be seen as citizenship rights (Jenson and Sineau, 2001).

Table 1: Maternal Employment Rates, Women 15-64 by Age Of Youngest Child, 2005

\begin{tabular}{lllllll}
\hline Country & 0-16 & $\begin{array}{l}\text { Under 2 } \\
\text { years }\end{array}$ & $\mathbf{3 - 5}$ years & $\mathbf{6 - 1 6}$ & $\begin{array}{l}\text { Two } \\
\text { children } \\
\text { under 15 }\end{array}$ & $\begin{array}{l}\text { Three } \\
\text { children } \\
\text { under 15 }\end{array}$ \\
\hline Canada & 70.5 & 58.7 & 68.1 & 71.1 & 73.2 & 66.3 \\
\hline Denmark & 76.5 & 71.4 & 77.8 & 77.5 & - & - \\
\hline New Zealand & 64.6 & 45.1 & 60.6 & 75.3 & 64.5 & 56.7 \\
\hline Sweden & 82.5 & 71.9 & 81.3 & 76.1 & 84.7 & 75.6 \\
\hline OECD & 61.5 & 51.9 & 61.3 & 66.3 & 57.0 & 44.0
\end{tabular}

Source: Extracted from OECD (2007a), Table 3.2

Table 2: Part-time Employment as a Percentage of Female and Male Employment, 2007

\begin{tabular}{lcc}
\hline Country & & 2007 \\
\hline New Zealand & Women & Men \\
\hline Canada & 34.7 & 11.2 \\
\hline Denmark & 26.1 & 11.0 \\
\hline Sweden & 23.9 & 12.4 \\
\hline OECD average & 19.7 & 9.5 \\
\hline
\end{tabular}

Source: Extracted from OECD (2009), p.73

Table 3: Poverty Rates For Children by Work Status Of their Parents

\begin{tabular}{lrrrrrr}
\hline & $\begin{array}{r}\text { Poverty } \\
\text { among } \\
\text { children }\end{array}$ & $\begin{array}{r}\text { Single } \\
\text { parent } \\
\text { not } \\
\text { working }\end{array}$ & $\begin{array}{r}\text { Single } \\
\text { parent } \\
\text { working }\end{array}$ & $\begin{array}{r}\text { Two } \\
\text { parents, } \\
\text { no worker }\end{array}$ & $\begin{array}{r}\text { Two } \\
\text { parents, } \\
\text { one } \\
\text { worker }\end{array}$ & $\begin{array}{r}\text { Two } \\
\text { parents, } \\
\text { two+ } \\
\text { workers }\end{array}$ \\
\hline New Zealand & 15 & 48 & 30 & 47 & 21 & 3 \\
\hline Canada & 15 & 89 & 32 & 81 & 22 & 4 \\
\hline Denmark & 3 & 20 & 4 & 21 & 5 & 0 \\
\hline Sweden & 4 & 18 & 6 & 36 & 14 & 1 \\
\hline OECD average & 12 & 54 & 21 & 48 & 16 & 4 \\
\hline
\end{tabular}

Source: Extracted from OECD (2009), p.93 
Until the 1960 s or later, both New Zealand and Canada expected mothers to care for their own children at home or find alternative care, but opposition to married women's employment was briefly challenged during the second world war when women's labour was needed in war industries (Baker and Tippin, 1999; Kedgley, 1996, p.132; May, 1997). For example, the Canadian government revised the Income Tax Act to allow husbands to claim their wives as dependants regardless of their earnings, and extended cost sharing to the provinces for daycare centres for mothers working
(Kedgley, 1996, p.303). However, when the National-led government returned, subsidies were reduced and the proposed funding increases were cancelled in 1991. A new programme called Parents as First Teachers was introduced to reinforce parental responsibility (ibid., p.304).

In 1991 the National-led government also cut the level of social benefits (including the $\mathrm{DPB}$ ), and later strengthened work requirements for beneficiaries. By 1997, sole mothers were expected to find part-time work when their youngest child entered school and full-time work when the youngest

\section{[The Canadian] Politicians were forced to listen} because maternal employment rates had already increased and public opinion considered child care crucial for women's employment equity as well as for children's education and development.

in war industries. However, these policies ended after the war (Pierson, 1977).

New Zealand governments continued to promote the male-breadwinner family, with support from the Plunket Society (Kedgley, 1996). Since 1973, sole parents have been provided with income support through the Domestic Purposes Benefit (DPB) if their income and assets are low, they have sole responsibility for the care of their children, and they have no male breadwinner in the household (Baker and Tippin, 1999). The Canadian provinces provide similar support, but their programmes always focused more on disadvantage and inability to work rather than sole mothering (ibid.).

In 1989, the New Zealand Labourled government showed a greater acceptance of maternal employment along with children's education and cultural development, and also tightened regulations and provided new ECEC funding. This policy change followed the Meade Report (1988) from the Working Group on Early Childhood Education, as well as lobbying by the Campaign for Quality Early Childhood Education child reached 14. Critics opposed these requirements by arguing that sole mothers were already working by caring for their children, but the changes went ahead. The National-led government continued to provide small subsidies for ECEC, but only for low-income households for 30 hours per week. Current policies were developed largely since the 1990s, when the rate of maternal employment accelerated, but Canadian policies were initiated in the 1960s. This suggests that higher male wages in New Zealand prior to the 1980 s enabled more wives to care at home, child care services were less affordable or available, and lobbying focused more on payments for maternal care at home (Baker, 2009).

Canadian governments have offered four main forms of support for ECEC. Since the 1950s, some of the provincial governments and school boards have funded free public kindergarten for fourand five-year-olds as part of the school system. The provincial/local governments also subsidise ECEC spaces for sole parents and low-income households (Baker, 2006), as well as providing income support for impoverished parents caring for infants and toddlers at home. In 1971, the federal government introduced an income tax deduction for employed parents using ECEC, especially reducing the tax payable for middle-income parents (ibid.). These latter three programmes were won after years of lobbying by organisations such as the Child Care Advocacy Association and the National Action Committee on the Status of Women (Baker and Tippin, 1999). Politicians were forced to listen because maternal employment rates had already increased and public opinion considered child care crucial for women's employment equity as well as for children's education and development.

From 1966 to 1996, the federal government matched provincial spending on social programmes (including ECEC) under the Canada Assistance Plan (CAP), designed to equalise provincial services (Baker, 2006). However, subsidised child care spaces continued to fall short of the demand as more mothers entered paid work, and employer-sponsored services were also encouraged through capital grants, operating subsidies and tax breaks. After considerable lobbying throughout the 1980s, two Canadian commissions studied child care concerns. In 1987 the Conservative (Mulroney) government introduced the National Strategy on Child Care, but only the tax reforms were implemented and the proposed national programme was delayed. As child care falls under provincial jurisdiction, the federal government was unable to persuade the provinces to accept national standards.

CAP was permitted to expire in 1996, largely because federal costs were growing and jurisdictional disputes continued. Instead, the Canadian government began transferring block grants to the provinces for health, social and educational services, permitting more variation in service delivery. Now that more households rely on maternal earnings, state support for child care has grown into a significant political issue in Canada.

\section{State child care support post-2000}

New Zealand and Canada continue to support low-income parental care as well as early childhood education and care (ECEC). Parental programmes 
typically enable low-income and sole parents (mainly mothers) to care for their children at home, as New Zealand's Domestic Purposes Benefit (DPB) and provincial welfare programmes in Canada do (Baker, 2008). ECEC programmes share many similarities between the two countries, but there are also notable cross-national differences. In Canada, kindergarten teachers' qualifications and the educational programmes continue to be regulated by the provincial ministries of education, while daycare centres with less-qualified providers (who focus more on play and custodial care) are subsidised and regulated by provincial ministries of social development or community services. In New Zealand, early childhood education is regulated by government and the 20 hours of free care (discussed later in this article) is funded by the Ministry of Education. However, child care subsidies to low-income families are provided through Work and Income New Zealand (WINZ, 2010).

Increasingly, the liberal states provide more free preschool education, subsidise full-day and full-week care for low-income parents, and have extended subsidies to for-profit providers (although they don't subsidise care by parents or relatives). Both New Zealand and Canada regulate the ECEC physical site and facilities, as well as provider qualifications and pay rates, parental fees, staff/child ratios and quality of educational programmes, but Canadian regulations vary considerably by province (Beach et al., 2009). As we will see in the following sections, recent reforms have been controversial in both countries.

\section{Recent New Zealand reforms}

In 1999 the Labour-led government returned to power, and in 2002 it officially relaxed National's work requirements for the DPB. However, it still expected beneficiaries to negotiate a 'Personal Development and Employment Plan' with case managers, emphasising employment when their children enter school (Baker and Tippin, 2004; RPAC, 2007). Major family policy reforms were made in 2006 when the 'Working for Families' programme provided more income support to employed parents with moderate and low incomes living with children. It also provided higher accommodation allowances, larger ECEC subsidies for up to 50 hours a week, and more out-of-school care (NZ Government, 2006; St John and Craig, 2004).

In 2007 the Labour-led government began subsidising 20 free hours of ECEC a week for three to four year olds in educational centres for a maximum of six hours per day, regardless of parental income (NZ Government, 2006). Bushouse (2009) argued that this was portrayed by Labour as a 'watershed' programme when it was introduced but had been controversial from the child enters school, and time limits have been placed on other programmes (WINZ website, 2010). Government subsidies for child care (beyond the 20 hours) remain partial: for the poorest parents ${ }^{3}$ the maximum is $\$ 3.77$ per hour in 2010 (WINZ, 2010). However, the government announced that it would cut the early childhood education budget in 2011 in order 'to slow the unsustainable rate of growth' under the previous Labour-led government (Binning, 2010). Subsidies will be reduced to ECEC providers with $80 \%$ or more of their staff fully qualified, which could increase parental fees, reduce

\section{... the [New Zealand] government announced that it would cut the early childhood education budget in 2011 in order 'to slow the unsustainable rate of growth' under the previous Labour-led government}

outset. In the initial proposal, private providers were excluded, but were later included after considerable lobbying by organisations such as the Early Childhood Council. Controversy continues about the exclusion of parent/whānau-led services and a restriction on 'top-up' fees. Bushouse (2009) demonstrated that this policy initiative has become the largest and most expensive early childhood programme in the country, and a major departure from funding targeted to lowincome households. In addition, she notes that about $35 \%$ of early childhood education in 2007 was privately owned (ibid., p.63). Many ECEC providers continue to argue that the 20-hours programme fails to cover their operating costs, requires them to ask parents to pay optional charges or lose money, and is really a higher subsidy on services rather than free care (Hann and Thomas, 2007; Bushouse, 2009).

Since the National-led government returned to power in 2008 they have retained the 20 hours but reactivated some of their previous income support policies. DPB mothers are required to enter employment when their youngest maternal employment and/or encourage parents to use lower quality care (ibid.). A task force was also established by the National-led government in October 2010 to review ECEC subsidies and services. However, another governmentappointed group (the Welfare Working Group) continues to discuss reforms to welfare funding, and is expected to focus on potential cuts.

Controversies continue about child care costs and service availability, and about the impact of day-long ECEC on children's development. However, research indicates that high-quality care improves school readiness and social skills while having little impact on maternal attachment or other behavioural indicators (Beach et al., 2009; Jenson and Sineau, 2001).

\section{Recent Canadian reforms}

Canadian controversies continue over the political feasibility of creating a national child care programme. The federal government funds a tax deduction for employment-related child care, now worth $\$ 7,000$ per preschool child, and ECEC spaces are subsidised by provincial/ 
local governments with federal grants. Consequently, costs vary considerably by province and community, and many centres have long waiting lists (Beach et al., 2009; Hoffman, 2010). Subsidised spaces are targeted to low-income and sole parents, but parents expected to pay the full cost may be eligible for the tax deduction.

Quebec heavily subsidises child care for all parents who need it, regardless of income or work status, at a cost to parents of $\$ 7.00$ Canadian 4 per day (Albanese, 2006). Inexpensive child care policies were initiated in 1997 by any child under six. This was allegedly designed to expand 'parental choice', but likely also to appease voters favouring mothering at home. At the provincial level, Ontario increased publicly-operated programmes in 2009 by introducing fullday public kindergarten for four and five year olds, requiring new partnerships between kindergarten teachers and ECEC providers (Lewington, 2010).

In Canada, the for-profit sector is growing faster than any other form of ECEC. Furthermore, the mean income among child care workers was \$25,100 in 2006 (CCRRU, 2008), which is well

\section{... rates have always been much higher in Canada than in New Zealand (OECD, 2009), influenced by eligibility for income support, male wages relative to living costs, and prevalent ideologies about 'good mothering' ...}

the centre-left Parti Québecois, which attempted to create a universal system. Through popular support, these policies were largely retained when the (Charest) Liberal government took over, using them to maximise maternal employment and provincial productivity (Adkin and Abu-Laban, 2008). Since those policies were introduced, full-time maternal employment rates increased in Quebec and are higher than in the rest of Canada (Statistics Canada, 2010). These rates have always been much higher in Canada than in New Zealand (OECD, 2009), influenced by eligibility for income support, male wages relative to living costs, and prevalent ideologies about 'good mothering' (Baker, 2009).

In 2004, Canada's Liberal (Martin) minority government attempted to create a national child care programme, promising to spend $\$ 5$ billion Canadian over five years (Adkin and Abu-Laban, 2008). However, when the current Conservative (Harper minority) government came into power in 2006 they cancelled these plans and introduced a child care benefit of $\$ 1,200$ per year for the parents of below average earnings, suggesting that this is often low-paid work. However, kindergarten teachers are paid at a much higher level. Advocacy groups continue to pressure governments to view the accessibility and affordability of child care as a policy issue influencing women's employment equity as well as children's education.

\section{Continuing child care controversies}

Public debates continue about whether the state should subsidise commercial operators and/or privilege non-family over family care (Bonoli and Reber, 2010). Conservatives typically support for-profit subsidies because they increase child care availability and affordability, but they could also compromise educational standards among providers who cut corners to maximise profits. Opponents of commercial subsidies have been particularly strong in Australia since the $\mathrm{ABC}$ Learning controversy and bankruptcy (Brennan, 2007b; Kruger et al., 2008). Conservatives also argue that families should be given a choice to care for their own children at home or to purchase care, but 'family' care is typically performed by mothers rather than fathers (Adkin and Abu-Laban, 2008). To create real choice, governments would have to pay benefits for home care approximating maternal earnings, which would be totally unaffordable and would require considerably higher income tax rates in Canada, but especially in New Zealand. ${ }^{5}$

Parents often require culturally sensitive child care, and Māori language preschools (kōhanga reo) have received international praise. However, like playcentres, the Māori preschools offer part-time education and care, and have relied largely on volunteers rather than qualified early childhood teachers. Immigrant mothers also need child care while working or taking language training. In addition, employees working non-standard hours need child care, but most centres operate during office hours. If parents work on different shifts they may be able to share care, but this could restrict family activities. Care by grandparents can save money, provide culturally sensitive care, and solidify the bond between generations, but increasingly both grandmothers as well as grandfathers are employed. Suitable child care is particularly difficult to find for children with disabilities or 'special needs'.

Some mothers care for preschoolers at home because they view it as their main pleasure and responsibility, while others find centre care unaffordable, low quality or unavailable in their community. Informal care by relatives and sitters remains a prevalent form of non-maternal child care but is seldom regulated by government. Furthermore, many of the controversies focus on ECEC. Affordable ECEC has been found to expand the labour supply, increase maternal employment and raise family income and national productivity (De Henau et al., 2006; Roy, 2006). In many European countries access to affordable ECEC is seen as an active labour market policy rather than a mechanism primarily to promote child development and education, or to reduce poverty.

\section{Funding and parental costs}

In 2004 (the most recent OECD data available, but before reforms in both countries), the average cost of child care 
relative to household earnings was higher in New Zealand than in Canada, but both exceeded the OECD average, as Table 4 indicates. Child care for sole parents with average earnings would have cost $27 \%$ of earnings in Canada but $42 \%$ in New Zealand (OECD, 2007, p.59). For two-parent households with one average earner, one low earner and two preschool children, child care would have cost about $20 \%$ of earnings in Canada and $26 \%$ in New Zealand. In Sweden and Denmark, however, these costs were $10 \%$ or less for all household types.

In 2005 (most recent data), public spending on ECEC was above the OECD average in New Zealand and higher than in Canada: $0.7 \%$ of the gross domestic product in New Zealand but less than $0.2 \%$ in Canada $^{6}$ (OECD, 2010, p.19). Furthermore, Canada's services seem to focus more on employment-related care, while New Zealand's emphasise early childhood education. The 20 hours introduced by the Labour-led government made a notable difference to those parents able to use it, although it is only for educational care for three to four year olds and insufficient spaces are available in many centres. A Ministry of Education report noted that parental child care fees fell by $30.3 \%$ since 2007 , while the average household income increased by $12.4 \%$ (Binning, 2010). While some Auckland parents $^{7}$ were previously paying over $\$ 1,000$ per month for full-week care, they paid closer to $\$ 480$ per month in 2010 . However, some ECEC providers view their services as educational and do not always accommodate parental employment hours. In addition, many parents who use the 20 hours must pay for additional care each week. Furthermore, children cannot use centre care when they are sick and many employed parents are ineligible for paid sick leave because they have not worked for the same employer for six months (Baker, 2008).

Canadian child care costs have also been reduced, with the expansion of heavily subsidised child care in Quebec and free all-day kindergarten in Ontario. Hoffman (2010) found that most of his respondents outside Quebec paid between $\$ 600$ and $\$ 800$ Canadian per month for full-time non-subsidised

Table 4: Child Care Costs as Percentage of Net Household Income for Working Couples and Lone Parents, 2004

\begin{tabular}{lrrrr}
\hline & $\begin{array}{r}\text { Two-earner families } \\
\text { (both with average } \\
\text { wages and 2 } \\
\text { children) }\end{array}$ & $\begin{array}{r}\text { Two-earner families } \\
\text { (1 with average } \\
\text { wage, 1 with low } \\
\text { wage and 2 children) }\end{array}$ & $\begin{array}{r}\text { Lone parent (1 } \\
\text { average wage and 2 } \\
\text { children) }\end{array}$ \\
\hline Newntry & 21 & 26 & 42 \\
\hline Canada & 18 & 20 & 27 \\
\hline Denmark & 9 & 10 & 9 \\
\hline Sweden & 6 & 7 & 5 \\
\hline OECD average & 15 & 17 & 17 \\
\hline
\end{tabular}

Source: OECD (2007b), p.59

centre-based child care. However, the cost of non-subsidised care for preschoolers varies considerably: from $\$ 399$ a week for full-day care in Manitoba to $\$ 814$ in Ontario, with higher fees for toddler and infant care (ibid.). One quarter of Canadian child care spaces are forprofit, and these providers now receive government subsidies in all provinces except Saskatchewan (Beach et al., 2009; CCRRU, 2008).

\section{Cross-national comparisons}

Despite years of research and knowledge about what constitutes quality care, broad cross-national variation exists in ECEC policies and programmes (Bonoli and Reber, 2010). Countries such as France have provided half-day preschool for children aged three to five as part of the education system, with about $99 \%$ of children attending (Leira, 2002, p.62). In the Nordic countries, left-of-centre political parties have supported public ECEC to promote gender equity, while parties in the political centre and right have promoted equal subsidies to all families with young children, regardless of their use of ECEC.

Of all OECD countries, Belgium, Denmark, France, Iceland and Sweden have provided more extensive ECEC services for preschool children at a lower cost to parents (Bonoli and Reber, 2010; Jenson and Sineau, 2001). As a percentage of net national income, Finland, Iceland and Denmark also spend significantly more on child care than pre-primary education (OECD, 2009, p.77). In the mid-20oos, total spending on ECEC in two-earner families as a percentage of the average wage was 6\% in Sweden and
Denmark, but it was $22 \%$ in Canada and $28 \%$ in New Zealand (OECD, 2010, p.21).

The social democratic countries also provide longer sick leave for employees. Sweden offers 14 days of paid leave per year (Eurofound, 2010), while New Zealand requires employers to provide only five days (Department of Labour, 2010). In Canada short-term employment leave falls under provincial jurisdiction, but Ontario (the largest province) does not require employers to provide any paid sick leave, although employees may negotiate this through collective agreements. The minimum wage as a percentage of the average wage also varies by country: $38 \%$ in Canada and $48 \%$ in New Zealand (OECD, 2007c, p.185). These discussions indicate the complexities of cross-national research, but also the extent of political trade-offs involved in policy development and implementation.

\section{Conclusion: mixed messages}

For decades Canada has had a strong employment-related child care lobby, a child care research and resource centre, and numerous researchers focusing on the topic, but jurisdictional disputes have prevented a national child care programme. In contrast, the New Zealand lobby has been dominated by ECEC providers and child poverty activists, who are more focused on early childhood education than maternal employment. Nevertheless, in both countries ECEC subsidies have been strengthened for moderate- and low-income parents who are studying, training or working for pay, and some free early education has been provided. Yet certain other family-related programmes have been eroded, especially by conservative governments. This 
includes income support for low-income mothers, although New Zealand policies remain considerably more generous than those in all Canadian provinces (Baker, 2008).

In addition, labour markets have been deregulated in both countries and a growing percentage of employees now work for low wages or in part-time positions with fewer work-related benefits (Lunt et al., 2008; Vosko, 2009). More mothers work full-time in Canada than in New Zealand, but the gender wage gap, the gap between minimum wages and average wages, and child poverty rates also remain higher in Canada (OECD, 2007b).

Liberal governments operating within global market conditions frequently promote mixed messages about the importance of family and paid work to the nation. They publicly reinforce the notion of parental responsibilities and talk about children as a future national resource, but increasingly emphasise the importance of paid work in the labour market more than caring work at home. Both New Zealand and Canada have elevated the importance of employment to family well-being but have not always ensured affordable or culturallyrelevant services, ECEC hours suitable for employed parents, emergency child care, sufficient sick leave to cover child illnesses, or adequate wages.

High-quality ECEC is essential for employed parents and gender equity, but working long hours or for low wages can easily undermine the time and effort required to create a healthy family life. The fact that both maternal employment and child poverty rates are higher in Canada suggests that parental employment is not a panacea for family well-being. Policy makers need to acknowledge that many parents struggle to combine earning and caring, and could benefit from the expansion of ECEC that is affordable, high-quality and considers their employment requirements as well as their children's education.

\footnotetext{
1 Part-time work is defined as 35 hours a week in Sweden and 30 hours in Canada and New Zealand.

2 Defined as households with children with less than $50 \%$ of household median income (after taxes and government transfers), adjusted for family size.

3 i.e. with household incomes of less than $\$ 1,200$ per week.

4 One NZ dollar was worth about 76 CND cents on 9 December 2010.

5 In 2010 the highest marginal income tax rate in New Zealand was 33\% (Inland Revenue website), compared to between $39 \%$ and $53 \%$ in Canada (29\% federal tax plus from between $10 \%$ and $24 \%$ provincial income tax) (Canada Revenue Agency website, 2010).

6 This figure seems to rely only on federal expenditures and I am not convinced that provincial day care subsidies are included.

7 An example of parents living in the moderate-income suburb of Mt Albert was provided.
}

\section{References}

Adkin, L. and Y. Abu-Laban (2008) 'The challenge of care: early childhood education and care in Canada and Quebec', Studies in Political Economy, 81, pp.49-76

Albanese, P. (2006) 'Small town, big benefits: the ripple effect of $\$ 7 /$ day child care', Canadian Review of Sociology and Anthropology, 43 (2), pp. $125-40$

Baker, M. (1995) Canadian Family Policies: cross-national comparisons, Toronto: University of Toronto Press

Baker, M. (2006) Restructuring Family Policies: convergences and divergences, Toronto: University of Toronto Press

Baker, M. (2008) 'Low-income mothers, employment and welfare restructuring', in N. Lunt, M. O'Brien and R. Stephens (eds), New Zealand, New Welfare, Auckland: CENGAGE Learning

Baker, M. (2009) 'Working their way out of poverty? Gendered employment in three welfare states', Journal of Comparative Family Studies, 40 (4), special issue, 'Patterns of Change and Continuity: understanding current transformations in family life' (ed. J. Baxter), pp.617-34

Baker, M. (2010) 'Motherhood, employment and the "Child Penalty"', Women's Studies International Forum, 33, pp.215-24

Baker, M. and D. Tippin (1999) Poverty, Social Assistance and the Employability of Mothers: restructuring welfare states, Toronto: University of Toronto Press

Baker, M. and D. Tippin (2004) 'More than just another obstacle: health, domestic purposes beneficiaries, and the transition to paid work', Social Policy Journal of New Zealand, 21 (March), pp.98-120

Beach, J., M. Friendly, C. Ferns, N. Prabhu and B. Forer (2009) Early Childhood Education and Care in Canada 2008, Toronto: Childcare Resource and Research Unit

Béland, D. (2005) 'Ideas and social policy: an institutionalist perspective', Social Policy and Administration, 39 (1), pp.1-18
Binning, E. (2010) 'Fears for affordability of preschool education', New Zealand Herald, 15 October

Bonoli, G. and F. Reber (2010) 'The political economy of childcare in OECD countries: explaining cross-national variation in spending and coverage rates', European Journal of Political Research, 49, pp.97118

Brennan, D. (2007a) 'Babies, budgets, and birthrates: work/family policy in Australia 1996-2006', Social Politics, 14 (1), pp.31-57

Brennan, D. (2007b) 'The ABC of child care politics', Australian Journal of Social Issues, 42 (2), pp.213-25

Bushouse, B. (2009) 'The 20 hours (free) programme: important choices ahead for New Zealand's new government', Policy Quarterly, 3 (1), pp.58-63

Castles, F.G. and I.F. Shirley (1996) 'Labour and social policy: gravediggers or refurbishers of the welfare state?', in F. Castles, R. Gerritsen and J. Vowles (eds), The Great Experiment: labour parties and public policy transformation in Australia, and New Zealand, Auckland: Auckland University Press

CCRRU (Childcare Resource and Research Unit) (2008) '30 quick facts about Canadian ECEC', Trends and Analysis 2008, www. childcarecanada.org

De Henau, J., D. Meulders and S. O'Dorchai (2006) 'The childcare triad? Indicators assessing three fields of child policies for working mothers in the EU-15', Journal of Comparative Policy Analysis, 8 (2), pp.12948

Esping-Andersen, G. (1990) The Three Worlds of Welfare Capitalism, Cambridge, UK: Polity Press

Eurofound (2010) 'Sick pay in Sweden', European Foundation for the Improvement of Living and Working Conditions, www.eurofound. europa.eu

Hann, A. and K. Thomas (2007) 'Threat to free care of young', The Press, 23 January 
Hantrais, L. (2004) Family Policy Matters: responding to family change in Europe, Bristol: The Policy Press

Hoffman, J. (2010) 'Child care costs across Canada', Today's Parent, 15 March

Jenson, J. and M. Sineau (eds) (2001) Who Cares? Women's work, childcare, and welfare state design, Toronto: University of Toronto Press

Kedgley, S. (1996) Mum's the Word: the untold story of motherhood in New Zealand, Auckland: Random House

Korpi, W. (2000) 'Faces of inequality: gender, class, and patterns of inequalities in different types of welfare states', Social Politics, 7 (2), pp.127-91

Kruger, C., S. Peatling and E. Jenson (2008) 'ABC Learning closures force 4000 to move', Sydney Morning Herald, 11 December

Leira, A. (2002) Working Parents and the Welfare State: family change and policy reform in Scandinavia, Cambridge, UK: Cambridge University Press

Lewington, J. (2010) 'All day kindergarten comes to Ontario', Professionally Speaking, 1 September

Lunt, N., M. O'Brien and R. Stephens (eds) (2008) New Zealand, New Welfare, Auckland: CENGAGE Learning

May, H. (1997) The Discovery of Childhood, Auckland/Wellington: Auckland University Press and Bridget Williams Books, with the New Zealand Council of Educational Research

McClure, M. (1998) A Civilised Community: a history of social security in New Zealand 1898-1998, Auckland: Auckland University Press

Meade, A. (1988) Education to be More: report of the Early Childhood Care and Education Working Group, Wellington: Department of Education

NZ Department of Labour (2010) 'Sick leave - general entitlements', www.dol.govt.nz

NZ Government (2006) Working for Families, www.workingforfamilies. govt.nz

O'Connor, J.S., A.S. Orloff and S. Shaver (1999) States, Markets, Families: gender liberalism and social policy in Australia, Canada, Great Britain and the United States, Cambridge, UK: Cambridge University Press
Ontario Ministry of Labour (2009) 'Leaves of absence, pregnancy, parental, personal emergency and family medical leave', Toronto: Ontario Ministry of Labour, www.labour.gov.on.ca

OECD (2007a) Babies and Bosses: reconciling work and family life (volume 5): a synthesis of findings for OECD countries, www/oecd.org/ els/social/family

OECD (2007b) Society at a Glance: OECD social indicators 2006, Paris: OECD

OECD (2007c) Benefits and Wages: OECD indicators, appendix, Paris: $\mathrm{OECD}$

OECD (2009) Society at a Glance: OECD social indicators 2009, Paris: OECD

OECD (2010) 'Gender Brief', Paris: OECD. Prepared by Social Policy Division, www.oecd.org/els/social

Pierson, R. (1977) 'Women's emancipation and the recruitment of women into the labour force in World War II', in S.M. Trofimenkoff and A. Prentice (eds), The Neglected Majority: essays in Canadian women's history, Toronto: McClelland and Stewart

Ranson, G. (2009) 'Paid and unpaid work: how do families divide their labour?', in M. Baker (ed.), Families: changing trends in Canada (6th edn), Toronto: McGraw-Hill Ryerson

RPAC (Rotorua Peoples Advocacy Centre) (2007) Improving Work/Life Balance for Domestic Purposes Beneficiary Sole Parent Families: an action research project, Rotorua, December

Roy, F. (2006) 'From she to she: changing patterns of women in the Canadian labour force', Canadian Economic Observer, 19 (6) (Statistics Canada)

St John, S. and D. Craig (2004) Cut Price Kids: does the 2004 'Working for Families' budget work for children?, Auckland: Child Poverty Action Group

Statistics Canada (2010) Wages, Salaries and Other Earnings, Ottawa: Statistics Canada, www40.statcan.ca

WINZ (Work and Income New Zealand) (2010) Help with childcare costs, www.workandincome.govt.nz

Vosko, L. (2009) 'Precarious employment and the challenges for employment policy', in M. Cohen and J. Pulkingham (eds), Public Policy for Women, Toronto: University of Toronto Press 